\title{
Milliliter per Centimeter of Water
}

National Cancer Institute

\section{Source}

National Cancer Institute. Milliliter per Centimeter of Water. NCI Thesaurus. Code C98755.

A unit of pressure expressed in milliliter(s) per centimeter of water. 